\title{
A systematic review of the traits and cognitions associated with use of and belief in complementary and alternative medicine (CAM).
}

\begin{abstract}
Complementary and alternative medicine (CAM) use is widespread despite the controversy over its effectiveness. Although previous reviews have examined the demographics and attitudes of CAM users, there is no existing review on the traits or cognitions which characterise either CAM users or those who believe in CAM effectiveness. The current systematic review set out to address these gaps in the literature by applying a narrative synthesis. A bibliographic search and manual searches were undertaken and key authors were contacted. Twenty-three papers were selected. The trait openness to experience was positively associated with CAM use but not CAM belief. Absorption and various types of coping were also positively associated with CAM use and belief. No other trait was reliably associated with CAM use or belief. Intuitive thinking and ontological confusions were positively associated with belief in CAM effectiveness; intuitive thinking was also positively associated with CAM use. Studies researching cognitions in CAM use/belief were mostly on non-clinical samples, whilst studies on traits and CAM use/belief were mostly on patients. The quality of studies varied but unrepresentative samples, untested outcome measures and simplistic statistical analyses were the most common flaws. Traits and cognition might be important correlates of CAM use and also of faith in CAM.
\end{abstract}

Key words: Complementary medicine, alternative medicine, traits, cognition, belief.

\section{Introduction}

Complementary and alternative medicine (CAM) encompasses treatments outside of conventional healthcare including acupuncture, herbal medicine, homoeopathy, massage and yoga (Zollman \& Vickers, 1999). Although CAM use is widespread (Harris, Cooper, Relton \& 
Thomas, 2012), prevalence and reasons for use (e.g. chronic or serious conditions, health promotion, prevention) vary across regions/countries (Eisenberg, Davis, Ettner, Appel, Wilkey, Van Rompay \& Kessler, 1998), perhaps due to diverging definitions of CAM (see Wheeler \& Hyland, 2008), but also economic conditions and availability of biomedical healthcare (Chibwana, Mathanga, Chinkhumba \& Campbell, 2009; Verhoef, Balneaves, Boon \& Vroegindewey, 2005).

Understanding the characteristics of CAM users is important because of doubts over CAM effectiveness and its evidence-base (Angell \& Kassirer, 1998; Barnes, 2003). Previous reviews suggest that psychological variables are powerful predictors of CAM use (Bishop, Yardley and Lewith 2007; Chang, Wallis \& Tiralongo, 2012), to date though, no-one has reviewed the cognitions (e.g. thinking style) or traits (e.g. openness to experience, OtE; see John \& Srivastava, 1999) which characterize CAM users, despite numerous empirical studies on these factors (e.g. Lindeman, 2011; Svedholm \& Lindeman, 2013 Sirios \& Gick, 2002) and despite evidence that cognition and traits predict health behavior and health beliefs (Smith, Williams, O'Donnell \& McKechnie, 2017). Furthermore, previous reviews have studied CAM use only, despite the role of beliefs in health behaviours (McEachan, Conner, Taylor \& Lawton, 2011) and furthermore CAM use does not necessarily imply belief in its efficacy (Verhoef et al., 2005).

\section{Study aims}

The first aim is to systematically review the cognitions and traits which characterise CAM users. The second aim is to review the cognitions and traits which are associated with beliefs in CAM effectiveness. We define cognition as 'mental processes...in perceiving, remembering, thinking and understanding' (Ashcraft \& Radvamsky, 2010, p9) and traits as stable and habitual patterns of affect, behavior and cognition (Zillig, Hemenover \& Dienstbier, 2002). 


\section{Method}

\section{Search strategy, information sources and eligibility criteria}

Online databases (Medline, embase, HIMC, CAB abstracts international, CINAHL, AMED, PsychINFO), reference lists and key journals were searched and prominent authors were contacted. The search-terms were: ("complementary medicine" or "alternative medicine" or "holistic medicine") and (personality or psychological or cogniti* or trait or "individual differences”). Following de-duplication, 685 titles remained. The inclusion criteria were: published in English between 1947 and 2016; non-expert population; measuring cognitions and/or traits; quantitative studies; the outcome measure was use of CAM or belief in CAM's effectiveness. The exclusion criteria were: not qualified or trainee health professionals, not healthcare providers; not studies on parents who advocate CAM for their children; not studies measuring only beliefs and attitudes which predict CAM use/beliefs; not studies of demographics, transient affect, epidemiology, prevalence or CAM effectiveness; not qualitative studies/reviews. The review was conducted in line with PRISMA guidelines (where appropriate) (see Moher, Liberati, Tetzlaff, Altman \& Prisma Group, 2009).

\section{Study selection and data collection}

Two raters independently screened 685 titles against inclusion criteria using PRISMA guidelines (see Figure 1), leaving $114(\kappa=.8)$. Following abstract screening and reference list searching, 29 papers remained, inconsistencies between raters were resolved collaboratively by referring to inclusion/exclusion criteria. After full-text screening, six further papers were removed, leaving 23. The summary measures were beta values, odds ratios or simple correlations ( $r$ ) (see Table 2).

Figure 1 near here

\section{Quality appraisal}


As most of the selected studies were correlational, risk of bias in individual studies (internal and external validity) was assessed using the NICE Quality appraisal checklist for quantitative studies reporting correlations and associations (NICE, 2006; see Table 1).

Table 1 near here

\section{Data synthesis}

The review was exploratory not hypothesis-driven, thus narrative analysis was conducted rather than meta-analysis. Studies were categorised according to whether clinical (i.e. participants recruited because of a specific medical diagnosis, see Table 2) or non-clinical samples. Personality traits and cognitions were examined separately. Trustworthiness of the analysis was assessed through discussion between the authors.

\section{Results}

\section{Clinical studies: personality variables}

Reported relationships were positive unless stated otherwise (study characteristics are in Table 2). OtE correlated with CAM use (Hogan, 2006; Lo-Fo-Wong, Ranchor, de Haes, Sprangers \& Henselmans, 2012), but not with CAM beliefs (Hogan, 2006). In contrast, Olchowska-Kotala (2013) found willingness-to-use CAM correlated negatively with OtE but positively with extraversion and neuroticism. Absorption correlated with using and believing in CAM (Owens, Taylor and Degood, 1999).

Table 2 near here

CAM use correlated with perceived control over health, and correlated negatively with beliefs that health is due-to-chance (Sirois, 2008), however, Lo-Fo-Wong et al. (2012) found no such relationships. Takeda Yamaguchi \& Yaegashi (2012) reported higher trait anxiety in CAM users. Tarhan, Alacacioglu, Somali, Sipahi, Zencir, Erten, ... \& Yilmaz. (2011) reported lower anxiety in CAM users, however they conflated state and trait anxiety. Positive affect correlated with using and believing in CAM (Owens et al., 1999). 
CAM use correlated with active coping, seeking social support, humour, planning (Suarez \& Reese, 1997; 2000), sense of coherence (Bonacchi, Fazzi, Toccafondi, Cantore, Mambrini, Muraca, ... \& Di Costanzo 2014), positive reinforcement-based motivations (Sirois, 2008) and resilience - which itself also correlated with CAM beliefs (Hogan, 2006). Coping with illness emotions was negatively associated with CAM use (Sirois, 2008).

\section{Clinical studies: cognitions}

Olchowska-Kotsala (2013) found that intuitive thinking and rational thinking were both positively related with willingness to use CAM.

\section{Non-clinical studies: personality variables}

OtE correlated with CAM use (Honda \& Jacobson, 2005; Lombart, 2002; Sirois \& Gick, 2002; Won, 2014) and with willingness-to-use CAM (Smith et al., 2008). OtE correlated with CAM beliefs (in US but not Asian students) in Ho (2012) but not in Furnham (2007), Hogan (2006) or Won (2014). Extraversion correlated with CAM beliefs in Furnham (2007) but negatively correlated with CAM use in Honda and Jacobson (2005). One non-clinical study reported a correlation between CAM use and absorption (Wheeler \& Hyland, 2008).

CAM use was negatively related to external coping but not related to lowering aspirations (Honda and Jacobson, 2005), nor to future-focused optimism (Smith, Dalen, Wiggins, Christopher, Bernard \& Shelley 2008). CAM use correlated with internal coping (Honda and Jacobson, 2005), active, support-seeking and avoidant coping (LaCaille \& Kuvaas, 2011). Spiritual-coping positively predicted willingness-to-use CAM (Smith et al., 2008).

Two non-clinical studies reported no relationship between locus of control and CAM use (Lombart, 2002; Sirois and Gick, 2002). One study noted a strong relationship between awareness of one’s feelings and willingness-to-use CAM (Smith et al., 2008). 


\section{Non-clinical studies: cognitions}

Three studies (Lindeman, 2011; Saher \& Lindeman, 2005; Svedholm \& Lindeman, 2013) found correlations between intuitive thinking and beliefs about CAM effectiveness. CAM use was associated with intuitive thinking (Wheeler \& Hyland, 2008; Won, 2014) and negatively associated with rational thought (Wheeler \& Hyland, 2008).

Additionally, three studies reported relationships between CAM beliefs and ontological confusions, i.e. mistaking the distinctions between physical, biological and mental phenomena such as describing processes (e.g. energy; Chen, 2007) as intentional (Lindeman, 2011; Lindeman \& Saher, 2007; Svedholm \& Lindeman, 2013).

\section{Discussion}

Intuitive thinking consistently predicted beliefs about CAM effectiveness and to a lesser extent CAM use, irrespective of study quality. Despite the availability of scientific evidence for orthodox medicine, CAM may be attractive because it appeals to emotions (see Verhoef et al., 2005) and does not rely on a broad scientific evidence base, this suits intuitive reasoners, even when they are aware that rational judgement has been overlooked (De Neys, Vartanian \& Goel, 2008). Evidence that CAM believers are also non-rational is inconsistent, illustrating the independence of these two thinking styles (Handley, Newstead \& Wright, 2000). A further cognitive style - ontological confusions - predicted belief in CAM effectiveness (Lindeman, 2011; Lindeman \& Saher, 2007; Svedholm \& Lindeman, 2012). This suggests that therapies based on ontologically unfounded principles (e.g. that energy can live or represent emotions), might be endorsed because some people are less able to detect ontological flaws inherent in the therapy.

OtE was related with CAM use although not with CAM beliefs. Thus, the notion that CAM users are more likely to try new and unconventional things is partially supported. No other big-five traits showed reliable relationships with CAM beliefs/use. Absorption was related to 
both CAM beliefs and CAM use, but only in two studies. Further research on this trait might also attempt to confirm its relationship with intuitive thinking. Coping was also related to CAM use, however definitions of coping varied. Associations between CAM and LoC and affect are ambiguous due to a paucity of studies and variation in quality, methodology and population.

There were no systematic differences between clinical and non-clinical studies regarding traits associated with CAM, however only one high-quality clinical study tested CAM beliefs. Thinking styles were mainly tested in non-clinical studies and no clinical studies tested ontological confusions - suggesting opportunities for future research.

\section{Conclusions, limitations and future research}

Although belief in CAM effectiveness is associated with cognitive bias, studies come mainly from Lindeman and colleagues’ research group on non-clinical Finnish populations which, limits the generalisability of this work. Indeed, all studies in the review were based in developed nations, and as economic and cultural contexts affect CAM use (e.g. Chibwana et al. 2009), more research is needed from developing nations, where biomedical treatment might be limited. Future research might test whether the relationship between intuitive thinking and CAM beliefs is upheld when using performance measures of thinking (such as the cognitive reflection test, Toplak, West \& Stanovich, 2011) rather than the self-report REI (Pacini \& Epsten, 1999), which does not correlate with performance tests of thinking (Newstead, Handley, Harley, Wright \& Farrelly, 2004). Additionally, numerous studies relied on simple correlations rather than multiple linear regression. Finally, future studies might address the paucity of reliable and valid CAM belief/use outcome measures.

\section{References}


Angell, M., \& Kassirer, J.P. (1998). Alternative medicine - The risks of untested and unregulated remedies. The New England Journal of Medicine, 339(12), 839-841. Doi: 10.1056/NEJM199809173391210

Ashcraft, M. H., \& Radvansky, G. A. (2010). Cognition (Fifth Edition). Pearson: Upper Saddle River, New Jersey, USA.

Barnes, P.M., Bloom, B., \& Nahin, R.L. (2008). Complementary and alternative medicine use among adults and children: United States, 2007. National health statistics reports; no 12. Hyattsville, MD: National Center for Health Statistics. Retrieved http://www.cdc.gov/nchs/data/nhsr/nhsr012.pdf

Bishop, F. L., Yardley, L., \& Lewith, G. T. (2007). A systematic review of beliefs involved in the use of complementary and alternative medicine. Journal of health psychology, 12, 851-867. Doi: $10.1177 / 1359105307082447$

Bonacchi, A., Fazzi, L., Toccafondi, A., Cantore, M., Mambrini, A., Muraca, M. G., ... \& Di Costanzo, F. (2014). Use and perceived benefits of complementary therapies by cancer patients receiving conventional treatment in Italy. Journal of pain and symptom management, 47, 26-34. Doi: http://dx.doi.org/10.1016/j.jpainsymman.2013.03.014

Chang, H., Wallis, M., \& Tiralongo, E. (2012). Predictors of complementary and alternative medicine use by people with type 2 diabetes. Journal of advanced nursing, 68, 1256-1266. Doi: 10.1111/j.1365-2648.2011.0582

Chen, X. (2007). The object bias and the study of scientific revolutions: Lessons from developmental psychology. Philosophical Psychology, 20, 479-503. Doi:10.1080/09515080701441744

Chibwana, A. I., Mathanga, D. P., Chinkhumba, J., \& Campbell, C. H. (2009). Socio-cultural predictors of health-seeking behaviour for febrile under-five children in Mwanza-Neno district, Malawi. Malaria journal, 8(1), 219. Doi: https://doi.org/10.1186/1475-2875-8-219 
De Neys, W., Vartanian, O., \& Goel, V. (2008). Smarter than we think when our brains detect that we are biased. Psychological Science, 19, 483-489. Doi: 10.1111/j.1467-9280.2008.02113.x. Eisenberg, D. M., Davis, R. B., Ettner, S. L., Appel, S., Wilkey, S., Van Rompay, M., \& Kessler, R. C. (1998). Trends in alternative medicine use in the United States, 1990-1997: results of a follow-up national survey. Jama, 280(18), 1569-1575. Doi: 10.1001/jama.280.18.1569

Furnham, A. (2007). Are modern health worries, personality and attitudes to science associated with the use of complementary and alternative medicine?. British journal of health psychology, 12, 229-243. Doi: 10.1348/135910706X100593

Handley, S.J., Newstead, S.E., \& Wright, H. (2000). Rational and experiential thinking: A study of the REI. In R Riding \& S. Rayner (Eds.). International perspectives on individual differences. Volume 1, Cognitive Styles (pp 97-113). Connecticut, USA: Ablex.

Harris, P.E., Cooper, K.L., Relton, C., \& Thomas, K.J. (2012). Prevalence of complementary and alternative medicine (CAM) use by the general population: a systematic review and update. International Journal of clinical practice,66(10), 924-939. Doi: 10.1111/j.17421241.2012.02945.x

Ho, J. S. (2012). Attitudes toward complementary and alternative medicine in college students as a function of nationality, familiarity, and personality traits. Unpublished doctoral thesis, Indiana State University.

Hogan, J. M. (2006). Individual differences as predictors of complementary and alternative medicine use in rheumatology patients. Unpublished doctoral thesis, University of Hawaii.

Honda, K., \& Jacobson, J. S. (2005). Use of complementary and alternative medicine among United States adults: the influences of personality, coping strategies, and social support. Preventive medicine, 40, 46-53. Doi: http://dx.doi.org/10.1016/j.ypmed.2004.05.001

John, O. P., \& Srivastava, S. (1999). The Big Five trait taxonomy: History, measurement, and theoretical perspectives. Handbook of personality: Theory and research, volume 2, (pp 102-138). New York, USA: Guildford Press. 
LaCaille, R. A., \& Kuvaas, N. J. (2011). Coping styles and self-regulation predict complementary and alternative medicine and herbal supplement use among college students. Psychology, health \& medicine, 16, 323-332. Doi: http://dx.doi.org/10.1080/13548506.2010.543909

Lindeman, M. (2011). Biases in intuitive reasoning and belief in complementary and alternative medicine. Psychology and Health, 26, 371-382. Doi: http://dx.doi.org/10.1080/08870440903440707

Lindeman, M., \& Saher, M. (2007). Vitalism, purpose and superstition. British Journal of Psychology, 98, 33-44. Doi: 10.1348/000712606X101808

Lo-Fo-Wong, D. N., Ranchor, A. V., de Haes, H. C., Sprangers, M. A., \& Henselmans, I. (2012). Complementary and alternative medicine use of women with breast cancer: self-help CAM attracts other women than guided CAM therapies. Patient education and counseling, 89, 529536. Doi: http://dx.doi.org/10.1016/j.pec.2012.02.019

Lombart, K. G. (2002). Unconventional therapies: Individual factors associated with use, perceptions of function and efficacy. Unpublished doctoral thesis, University of Louisville.

McEachan, R. R. C., Conner, M., Taylor, N. J., \& Lawton, R. J. (2011). Prospective prediction of health-related behaviours with the theory of planned behaviour: A meta-analysis. Health Psychology Review, 5(2), 97-144. Doi: https://doi.org/10.1080/17437199.2010.521684

Moher, D., Liberati, A., Tetzlaff, J., Altman, D. G., \& Prisma Group. (2009). Preferred reporting items for systematic reviews and meta-analyses: the PRISMA statement. PLoS medicine, 6(7), e1000097. Doi: https://doi.org/10.1371/journal.pmed.1000097

Newstead, S. E., Handley, S. J., Harley, C., Wright, H., \& Farrelly, D. (2004). Individual differences in deductive reasoning. Quarterly Journal of Experimental Psychology Section A, 57, 33-60. Doi:10.1080/02724980343000116 
NICE (2006). Methods for the development of NICE public health guidance (third edition). Retrieved from: https:/www.nice.org.uk/process/pmg4/chapter/appendix-g-quality-appraisalchecklist-quantitative-studies-reporting-correlations-and

Olchowska-Kotala, A. (2013). Individual differences in cancer patients' willingness to use complementary and alternative medicine. Advances in Clinical and Experimental Medicine, 22, 855-860.

Owens, J. E., Taylor, A. G., \& Degood, D. (1999). Complementary and alternative medicine and psychologic factors: toward an individual differences model of complementary and alternative medicine use and outcomes. The Journal of Alternative and Complementary Medicine, 5(6), 529541. Doi: https://doi.org/10.1089/acm.1999.5.529

Pacini, R., \& Epstein, S. (1999). The relation of rational and experiential information processing styles to personality, basic beliefs, and the ratio-bias phenomenon. Journal of Personality and Social Psychology, 76, 972-987. Doi: http://dx.doi.org/10.1037/0022-3514.76.6.972

Saher, M., \& Lindeman, M. (2005). Alternative medicine: A psychological perspective. Personality and individual differences, 39, 1169-1178. Doi: http://dx.doi.org/10.1016/j.paid.2005.04.008

Sirois, F. M. (2008). Provider-based complementary and alternative medicine use among three chronic illness groups: associations with psychosocial factors and concurrent use of conventional health-care services. Complementary therapies in medicine, 16, 73-80. Doi: http://dx.doi.org/10.1016/j.ctim.2007.03.006

Sirois, F. M., \& Gick, M. L. (2002). An investigation of the health beliefs and motivations of complementary medicine clients. Social science \& medicine, 55, 1025-1037. Doi: http://dx.doi.org/10.1016/S0277-9536(01)00229-5

Smith, B. W., Dalen, J., Wiggins, K. T., Christopher, P. J., Bernard, J. F., \& Shelley, B. M. (2008). Who is willing to use complementary and alternative medicine?. Explore: The Journal of Science and Healing, 4, 359-367. Doi: http://dx.doi.org/10.1016/j.explore.2008.08.001 
Smith, G., Williams, L., O'Donnell, C., \& McKechnie, J. (2017). The influence of socialcognitive constructs and personality traits on physical activity in healthy adults. International Journal of Sport and Exercise Psychology, 15(5), 540-555.

Svedholm, A. M., \& Lindeman, M. (2013). Healing, mental energy in the physics classroom: Energy conceptions and trust in complementary and alternative medicine in grade 10-12 students. Science \& Education, 22, 677-694. Doi: 10.1007/s11191-012-9529-6

Suarez, T., \& Reese, F. L. (1997). Alternative medicine use, perceived control, coping, and adjustment in African American and Caucasian males living with HIV and AIDS. International Journal of Rehabilitation and Health, 3(2), 107-118.

Suarez, T., \& Reese, F. L. (2000). Coping, psychological adjustment, and complementary and alternative medicine use in persons living with HIV and AIDS. Psychology and Health, 15(5), 635-649. Doi: https://doi.org/10.1080/08870440008405476

Takeda, T., Yamaguchi, T., \& Yaegashi, N. (2012). Perceptions and attitudes of Japanese gynecologic cancer patients to Kampo (Japanese herbal) medicines. International journal of clinical oncology, 17, 143-149. Doi: 10.1007/s10147-011-0271-х

Tarhan, O., Alacacioglu, A., Somali, I., Sipahi, H., Zencir, M., Erten, C., ... \& Yilmaz, U. (2011). The association of complementary alternative medicine use with anxiety, depression and quality of life in Turkish cancer patients. Wspolczesna onkologia-contemporary oncology, 15, 274-278. Doi: 10.5114/wo.2011.25655

Toplak, M. E., West, R.F., \& Stanovich, K. E. (2011). The Cognitive Reflection Test as a predictor of performance on heuristics-and-biases tasks. Memory \& Cognition, 39, 1275-1289. Doi:10.3758/s13421-011-0104-1.

Verhoef, M. J., Balneaves, L.G., Boon, H.S., \& Vroegindewey, A. (2005). Reasons for and characteristics associated with complementary and alternative medicine use among adult cancer patients: a systematic review. Integrative Cancer Therapies, 4, 274-286. Doi: $10.1177 / 1534735405282361$ 
Wheeler, P., \& Hyland, M. E. (2008). Dispositional predictors of complementary medicine and vitamin use in students. Journal of health psychology, 13(4), 516-519. Doi: https://doi.org/10.1177/1359105308088522

Won, C. J. (2014). Personality, emotional intelligence, intuitive thinking and attitude towards complementary and alternative medicine. Unpublished doctoral thesis, Alliant International University.

Zillig, L. M. P., Hemenover, S. H., \& Dienstbier, R. A. (2002). What do we assess when we assess a Big 5 trait? A content analysis of the affective, behavioral, and cognitive processes represented in Big 5 personality inventories. Personality and Social Psychology Bulletin, 28(6), 847-858. Doi: https://doi.org/10.1177/0146167202289013

Zollman, C., \& Vickers, A. (1999). What is complementary medicine? Bmj, 319, 693-696. Doi: http://dx.doi.org/10.1136/bmj.319.7211.693. 
Table 1. The quality of the studies included in the review, assessed by the NICE Quality appraisal checklist for quantitative studies reporting correlations and associations (NICE, 2006).

\begin{tabular}{|c|c|c|c|c|c|c|c|c|c|c|c|c|}
\hline & 1.1 & 1.2 & 1.3 & 2.2 & 2.4 & 3.1 & 4.1 & 4.2 & 4.3 & 4.6 & $\begin{array}{l}\text { 5.1Study results } \\
\text { internally valid? }\end{array}$ & $\begin{array}{l}5.2 \text { Findings generalisable to the } \\
\text { source population (i.e. } \\
\text { externally valid)? }\end{array}$ \\
\hline Bonacchi et al. (2014) & ++ & + & ++ & ++ & ++ & - & + & + & + & + & + & ++ \\
\hline Furnham (2007) & ++ & ++ & + & ++ & - & + & ++ & - & - & + & + & + \\
\hline Но (2012) & ++ & + & - & ++ & + & - & ++ & + & + & ++ & + & + \\
\hline Hogan (2006) & & + & ++ & ++ & ++ & ++ & ++ & ++ & ++ & ++ & ++ & ++ \\
\hline Honda \& Jacobson (2005) & ++ & ++ & ++ & ++ & ++ & + & ++ & ++ & ++ & ++ & ++ & ++ \\
\hline LaCaille \& Kuvaas (2011) & + & + & ++ & ++ & + & - & ++ & + & + & ++ & + & + \\
\hline Lindeman (2011) & ++ & ++ & + & ++ & ++ & + & + & ++ & ++ & ++ & ++ & ++ \\
\hline Lindeman \& Saher (2007) & ++ & + & - & ++ & - & ++ & + & - & - & + & + & + \\
\hline Lo-Fo-Wong et al. (2012) & + & ++ & ++ & ++ & ++ & - & ++ & ++ & ++ & ++ & ++ & ++ \\
\hline Lombart (2002) & ++ & - & - & ++ & - & - & ++ & + & ++ & + & + & - \\
\hline Olchowska-Kotala (2013) & - & - & - & ++ & + & + & - & ++ & + & ++ & + & - \\
\hline Owens et al. (1999) & + & ++ & + & ++ & + & + & ++ & + & + & ++ & ++ & + \\
\hline Saher \& Lindeman (2005) & + & - & - & ++ & ++ & + & ++ & ++ & ++ & + & + & - \\
\hline Sirois (2008) & ++ & + & + & ++ & ++ & - & ++ & ++ & ++ & ++ & ++ & + \\
\hline Sirois \& Gick (2002) & ++ & + & + & ++ & - & - & ++ & - & - & ++ & + & + \\
\hline Smith et al. (2008) & ++ & - & - & ++ & ++ & ++ & ++ & ++ & ++ & ++ & ++ & - \\
\hline Suarez \& Reese (1997) & ++ & + & + & ++ & ++ & ++ & - & + & ++ & ++ & ++ & + \\
\hline Suarez \& Reese (2000) & + & + & ++ & ++ & ++ & + & + & ++ & ++ & ++ & ++ & + \\
\hline Svedholm \& Lindeman (2013) & + & NR & NR & ++ & - & + & + & - & - & + & + & - \\
\hline Takeda et al. (2012) & ++ & + & + & ++ & ++ & - & ++ & ++ & ++ & ++ & + & + \\
\hline Tarhan et al. (2011) & + & NR & + & ++ & - & - & ++ & - & - & ++ & - & - \\
\hline Wheeler \& Hyland (2008) & + & + & + & ++ & - & + & ++ & + & + & ++ & ++ & + \\
\hline Won, (2014) & ++ & + & + & ++ & ++ & + & + & ++ & ++ & ++ & ++ & + \\
\hline
\end{tabular}

Note: 1.1 Source population well described?; 1.2 Eligible population or area representative of the source population or area?; 1.3 Selected participants or areas represent the eligible population or area?; 2.2 Selection of explanatory variables based on a sound theoretical basis?; 2.4 Likely confounding factors identified and controlled?; 3.1 Outcome measures and procedures reliable?; 4.1 Sufficiently powered?; 4.2 Multiple explanatory variables considered in the analyses?; 4.3 Analytical methods appropriate?; 4.6 Precision of association given or calculable? Is association meaningful?; 5.1Study results internally valid?; 5.2 Findings generalisable to the source population (i.e. externally valid)?; NR = not recorded. 
Table 2, part 1 . Summary of the studies included in the review.

\begin{tabular}{|c|c|c|c|c|c|c|c|c|}
\hline Authors & Bonacchi et al. & Furnham & Ho & Hogan & Honda \& Jacobson & LaCaille \& Kuvaas & Lindeman & Lindeman \& Saher \\
\hline Year & 2014 & 2007 & 2012 & 2006 & 2005 & 2011 & 2011 & 2007 \\
\hline Country & Italy & UK & UK, Asia & USA & USA & USA & Finland & Finland \\
\hline Setting & $\begin{array}{l}\text { Secondary care, } \\
\text { cancer }\end{array}$ & General public & US, Asia & $\begin{array}{l}\text { Secondary care, } \\
\text { rheumatology }\end{array}$ & $\begin{array}{l}\text { US general } \\
\text { population }\end{array}$ & College & General public & University/ school \\
\hline Population & $\begin{array}{l}\text { Italian cancer } \\
\text { patients }\end{array}$ & UK general public & $\begin{array}{l}\text { General } \\
\text { population }\end{array}$ & $\begin{array}{l}\text { US rheumatology } \\
\text { patients }\end{array}$ & $\begin{array}{l}\text { US general } \\
\text { population }\end{array}$ & US College students & General public & Students \\
\hline Sample size & 803 & 243 & 148 & 320 & 3032 & 370 & 1092 & 239 \\
\hline Study aims & $\begin{array}{l}\text { Demographic and } \\
\text { psychological } \\
\text { characteristics of } \\
\text { CAM users }\end{array}$ & $\begin{array}{l}\text { Whether personality, } \\
\text { beliefs and attitudes } \\
\text { predict beliefs/ } \\
\text { attitudes to CAM and } \\
\text { use of CAM }\end{array}$ & $\begin{array}{l}\text { Predictors of } \\
\text { attitudes to CAM }\end{array}$ & $\begin{array}{l}\text { Relationships between } \\
\text { self-reported health, } \\
\text { personality variables } \\
\text { and the use and } \\
\text { effectiveness of CAM }\end{array}$ & $\begin{array}{l}\text { Association } \\
\text { between CAM use } \\
\text { \& personality, } \\
\text { coping, social } \\
\text { support }\end{array}$ & $\begin{array}{l}\text { CAM use \& } \\
\text { associations with } \\
\text { coping and self- } \\
\text { regulatory styles, } \\
\text { healthcare satisfaction }\end{array}$ & $\begin{array}{l}\text { Compare cognitions, } \\
\text { beliefs and } \\
\text { demographic } \\
\text { predictors of belief } \\
\text { in CAM }\end{array}$ & $\begin{array}{l}\text { Association between } \\
\text { ontological } \\
\text { confusions and } \\
\text { superstitious beliefs } \\
\text { (including CAM) }\end{array}$ \\
\hline Design & $\begin{array}{l}\text { Correlational, } \\
\text { cross-sectional }\end{array}$ & $\begin{array}{l}\text { Correlational, cross- } \\
\text { sectional }\end{array}$ & $\begin{array}{l}\text { Correlational, } \\
\text { cross-sectional }\end{array}$ & $\begin{array}{l}\text { Correlational, cross- } \\
\text { sectional }\end{array}$ & $\begin{array}{l}\text { Correlational, } \\
\text { cross-sectional }\end{array}$ & $\begin{array}{l}\text { Correlational, cross- } \\
\text { sectional }\end{array}$ & $\begin{array}{l}\text { Correlational, cross- } \\
\text { sectional }\end{array}$ & $\begin{array}{l}\text { Correlational, cross- } \\
\text { sectional }\end{array}$ \\
\hline $\begin{array}{l}\text { Outcome } \\
\text { measure }\end{array}$ & $\begin{array}{l}\text { Self-reported } \\
\text { current and past } \\
\text { use of CAM }\end{array}$ & $\begin{array}{l}\text { Belief in efficacy of } \\
\text { CAM, attitude to } \\
\text { CAM, safety of CAM }\end{array}$ & $\begin{array}{l}\text { Self-reported } \\
\text { attitudes to } \\
\text { alternative } \\
\text { medicine }\end{array}$ & $\begin{array}{l}\text { CAM use and ratings of } \\
\text { effectiveness of CAM }\end{array}$ & $\begin{array}{l}\text { Self-reported use of } \\
\text { any CAM in past } \\
\text { year }\end{array}$ & $\begin{array}{l}\text { Self-reported use of } \\
\text { CAM and herbals } \\
\text { supplements in past } \\
\text { year }\end{array}$ & $\begin{array}{l}\text { Self-reported belief } \\
\text { in CAM }\end{array}$ & $\begin{array}{l}\text { Self-reported belief in } \\
\text { efficacy of CAM }\end{array}$ \\
\hline $\begin{array}{l}\text { Outcome } \\
\text { measure tested } \\
\text { for reliability } \\
\text { and validity? }\end{array}$ & Not tested & $\begin{array}{l}\text { Content/ construct } \\
\text { validity }\end{array}$ & Not tested & $\begin{array}{l}\text { Internal reliability, } \\
\text { discriminant validity }\end{array}$ & Content validity & Not tested & Internal consistency & Internal consistency \\
\hline Analysis & Regression & Correlations & Regression & $\begin{array}{l}\text { Regressions for total } \\
\text { CAM use }\end{array}$ & Regression & Regression & Regression & Simple correlations \\
\hline
\end{tabular}


Table 2, part 2. Summary of the studies included in the review.

\begin{tabular}{|c|c|c|c|c|c|c|c|c|c|c|c|}
\hline Authors & $\begin{array}{l}\text { Bonacchi et } \\
\text { al. }\end{array}$ & Furnham & Ho & Hogan & & & Honda \& Ja & obson & $\begin{array}{l}\text { LaCaille \& } \\
\text { Kuvaas }\end{array}$ & Lindeman & $\begin{array}{l}\text { Lindeman \& } \\
\text { Saher }\end{array}$ \\
\hline $\begin{array}{l}\text { Cognitions/traits } \\
\text { related to CAM } \\
\text { use or belief }\end{array}$ & $\begin{array}{l}\text { Sense of } \\
\text { coherence } \\
\& \text { past use } \\
\text { of CAM } \\
(\mathrm{OR}=1.6,)\end{array}$ & $\begin{array}{l}\text { Extraversion } \\
\text { correlated with } \\
\text { efficacy of CAM } \\
(r=.15) \text {; } \\
\text { agreeableness } \\
\text { correlated with } \\
\text { safety }(r=.16)\end{array}$ & $\begin{array}{l}\text { OtE, } \\
\text { (American } \\
\text { students, } \beta \\
=.276 \text { ) }\end{array}$ & $\begin{array}{l}\text { Total CAM } \\
\text { use: } \\
\text { absorption } \\
\text { ( } \beta=.396) ; \\
\text { OtE }(\beta \\
=.259) ;\end{array}$ & $\begin{array}{l}\text { Practitioner-led } \\
\text { CAM use: } \\
\text { (OtE }(r=.27) ; \\
\text { absorption } \\
(r=.27)\end{array}$ & $\begin{array}{l}\text { Self-CAM } \\
\text { use: } \\
\text { Resilience } \\
(\beta=.170) \text {; }\end{array}$ & $\begin{array}{l}\text { Any CAM } \\
\text { use: } \\
\text { resilience } \\
(\beta=.136) ; \\
\text { positive } \\
\text { affect ( } \beta \\
=.138) ;\end{array}$ & $\begin{array}{l}\text { OtE, }(\mathrm{OR}=1.65) ; \\
\text { Extraversion } \\
\text { (OR=0.65); } \\
\text { Persistence } \\
\text { (OR=0.67); } \\
\text { Positive } \\
\text { reappraisals predict } \\
\text { some types of } \\
\text { CAM. }\end{array}$ & $\begin{array}{l}\text { CAM: Intrinsic } \\
\text { self-regulatory } \\
\text { style (OR =1.12); } \\
\text { Active coping } \\
\text { (OR=1.11); } \\
\text { Support seeking } \\
\text { coping (OR= } \\
\text { 1.07); Herbal: } \\
\text { Avoidant coping } \\
\text { (OR=1.06); } \\
\text { Active coping } \\
\text { (OR=1.11) }\end{array}$ & $\begin{array}{l}\text { Intuitive } \\
\text { thinking } \\
(\beta=.13 \text {; core } \\
\text { knowledge } \\
\text { confusions } \\
(\beta=.16)\end{array}$ & $\begin{array}{l}\text { Ontological } \\
\text { confusions, } \\
\text { correlations } \\
\text { ranging from } \\
r=.31 \text { to } \\
r=.75\end{array}$ \\
\hline $\begin{array}{l}\text { Cognitions/traits } \\
\text { NOT related to } \\
\text { CAM use or } \\
\text { belief }\end{array}$ & $\begin{array}{l}\text { SoC and } \\
\text { current use } \\
\text { of CAM }\end{array}$ & $\begin{array}{l}\text { Neuroticism, OtE, } \\
\text { conscientiousness } \\
(\mathrm{r}<.15)\end{array}$ & $\begin{array}{l}\text { OtE (Asian } \\
\text { students, } \beta \\
=.194 \text { ) }\end{array}$ & $\begin{array}{l}\text { Total CAM } \\
\text { use: } \\
\text { positive } \\
\text { affect ( } \beta \\
=.025 \text { ); }\end{array}$ & $\begin{array}{l}\text { CAM } \\
\text { effectiveness: } \\
\text { OtE ( } r=-.05) \text {; } \\
\text { absorption } \\
(r=.07)\end{array}$ & & & $\begin{array}{l}\text { Agreeableness } \\
\text { (OR=1.06); } \\
\text { Neurot. } \\
\text { (OR=0.88); } \\
\text { Conscient. } \\
\text { (OR=0.94); Pos. } \\
\text { reappraisals } \\
\text { (OR=1.20); } \\
\text { Lowering } \\
\text { aspirations } \\
(\mathrm{OR}=0.86)\end{array}$ & $\begin{array}{l}\text { CAM use: } \\
\text { Avoidant coping } \\
\text { OR= 0.99; } \\
\text { Acceptance } \\
\text { coping OR= } 0.93 \text {; } \\
\text { Need for cognition } \\
\text { OR=1.02; Various } \\
\text { motiv. types } \\
\text { OR=1.01 to } \\
\text { OR=0.96; }\end{array}$ & / & / \\
\hline
\end{tabular}


Table 2, part 3. Summary of the studies included in the review.

\begin{tabular}{|c|c|c|c|c|c|c|c|c|c|c|c|}
\hline Authors & $\begin{array}{l}\text { Lo-Fo-Wong, } \\
\text { et al. }\end{array}$ & Lombart, K. & $\begin{array}{l}\text { Olchowska- } \\
\text { Kotsala, }\end{array}$ & Owens et al. & $\begin{array}{l}\text { Saher, \& } \\
\text { Lindeman }\end{array}$ & Sirois & Sirois \& Gick & Smith,et al. & $\begin{array}{l}\text { Suarez \& } \\
\text { Reese }\end{array}$ & $\begin{array}{l}\text { Suarez \& } \\
\text { Reese }\end{array}$ & $\begin{array}{l}\text { Svedholm \& } \\
\text { Lindeman }\end{array}$ \\
\hline Year & 2012 & 2002 & 2013 & 1999 & 2005 & 2008 & 2002 & 2008 & 1997 & 2000 & 2013 \\
\hline Country & Nether-lands & USA & Poland & USA & Finland & Canada & Canada & USA & USA & USA & Finland \\
\hline Setting & $\begin{array}{l}\text { Secondary } \\
\text { care, cancer }\end{array}$ & $\begin{array}{l}\text { University, gen. } \\
\text { public }\end{array}$ & $\begin{array}{l}\text { Secondary } \\
\text { care, cancer }\end{array}$ & $\begin{array}{l}\text { Secondary } \\
\text { care, cancer; } \\
\text { community }\end{array}$ & $\begin{array}{l}\text { School, } \\
\text { university, gen. } \\
\text { public }\end{array}$ & Online & $\begin{array}{l}\text { Orthodox } \\
\text { medicine health } \\
\text { offices/clinics, } \\
\text { compl. } \\
\text { medicine health } \\
\text { offices/clinics }\end{array}$ & University & $\begin{array}{l}\text { Secondary } \\
\text { care, HIV }\end{array}$ & $\begin{array}{l}\text { Secondary } \\
\text { care, HIV; } \\
\text { primary care }\end{array}$ & $\begin{array}{l}\text { Secondary } \\
\text { school }\end{array}$ \\
\hline Population & $\begin{array}{l}\text { Dutch female } \\
\text { breast cancer } \\
\text { patients }\end{array}$ & $\begin{array}{l}\text { Students, gen. } \\
\text { public }\end{array}$ & $\begin{array}{l}\text { Polish cancer } \\
\text { patients }\end{array}$ & $\begin{array}{l}\text { Cancer } \\
\text { patients, pain } \\
\text { patients, } \\
\text { community }\end{array}$ & $\begin{array}{l}\text { Students, gen. } \\
\text { public in } \\
\text { Finland }\end{array}$ & $\begin{array}{l}\text { Arthritis, IBS, } \\
\text { mixed chronic } \\
\text { conditions } \\
\text { patients }\end{array}$ & $\begin{array}{l}\text { CAM users and } \\
\text { non-CAM users }\end{array}$ & $\begin{array}{l}\text { US undergrad. } \\
\text { students }\end{array}$ & $\begin{array}{l}\text { HIV-positive } \\
\text { men }\end{array}$ & $\begin{array}{l}\text { HIV-positive } \\
\text { individuals }\end{array}$ & $\begin{array}{l}\text { Secondary } \\
\text { school students } \\
\text { in Finland }\end{array}$ \\
\hline $\begin{array}{l}\text { Sample } \\
\text { size }\end{array}$ & 176 & 160 & 49 & 186 & 3261 & 365 & 199 & 276 & 73 & 127 & 102 \\
\hline $\begin{array}{l}\text { Study } \\
\text { aims }\end{array}$ & $\begin{array}{l}\text { Socio- } \\
\text { demographic, } \\
\text { clinical, and } \\
\text { psychological } \\
\text { predictors of } \\
\text { CAM use }\end{array}$ & $\begin{array}{l}\text { Psychological } \\
\text { and } \\
\text { demographic } \\
\text { correlates of } \\
\text { perceived } \\
\text { efficacy and use } \\
\text { of } \\
\text { unconventional } \\
\text { therapies (UT) }\end{array}$ & $\begin{array}{l}\text { Whether } \\
\text { personality, } \\
\text { cognitive } \\
\text { preferences, } \\
\text { and } \\
\text { paranormal } \\
\text { beliefs predict } \\
\text { willingness to } \\
\text { use CAM }\end{array}$ & $\begin{array}{l}\text { To assess } \\
\text { whether CAM } \\
\text { use was } \\
\text { associated } \\
\text { with affect } \\
\text { and absorption }\end{array}$ & $\begin{array}{l}\text { Do intuitive } \\
\text { thinking, } \\
\text { paranormal } \\
\text { beliefs, } \\
\text { magical } \\
\text { food/health } \\
\text { beliefs, values } \\
\text { and sex predict } \\
\text { CAM beliefs. }\end{array}$ & $\begin{array}{l}\text { Studying the } \\
\text { socio- } \\
\text { demographic, } \\
\text { health-related, } \\
\text { and } \\
\text { psychosocial } \\
\text { correlates of } \\
\text { CAM use }\end{array}$ & $\begin{array}{l}\text { Whether health } \\
\text { beliefs, socio- } \\
\text { demographic, } \\
\text { medical, and } \\
\text { personality } \\
\text { factors } \\
\text { predicted CAM } \\
\text { use. }\end{array}$ & $\begin{array}{l}\text { To study } \\
\text { individual } \\
\text { difference in } \\
\text { personality in } \\
\text { willingness to } \\
\text { use CAM }\end{array}$ & $\begin{array}{l}\text { To study } \\
\text { relationships } \\
\text { between CAM } \\
\text { use, perceived } \\
\text { control, stress } \\
\text { appraisal , } \\
\text { adjustment and } \\
\text { coping }\end{array}$ & $\begin{array}{l}\text { To study } \\
\text { relationships } \\
\text { between CAM } \\
\text { use, stress } \\
\text { appraisal and } \\
\text { coping }\end{array}$ & $\begin{array}{l}\text { Whether } \\
\text { ontological } \\
\text { confusions and } \\
\text { cognitive style } \\
\text { were } \\
\text { associated with } \\
\text { ratings of } \\
\text { CAM } \\
\text { effectiveness }\end{array}$ \\
\hline Design & $\begin{array}{l}\text { Cross- } \\
\text { sectional } \\
\text { (correlational) } \\
\text { and long'l }\end{array}$ & $\begin{array}{l}\text { Correlational, } \\
\text { cross-sectional }\end{array}$ & $\begin{array}{l}\text { Correlational, } \\
\text { cross-sectional }\end{array}$ & $\begin{array}{l}\text { Correlational, } \\
\text { cross-sectional }\end{array}$ & $\begin{array}{l}\text { Correlational, } \\
\text { cross-sectional }\end{array}$ & $\begin{array}{l}\text { Correlational, } \\
\text { cross-sectional }\end{array}$ & $\begin{array}{l}\text { Quasi } \\
\text { experimental } \\
\text { comparison, } \\
\text { cross sectional }\end{array}$ & $\begin{array}{l}\text { Correlational, } \\
\text { cross-sectional }\end{array}$ & $\begin{array}{l}\text { Correlational, } \\
\text { cross-sectional }\end{array}$ & $\begin{array}{l}\text { Correlational, } \\
\text { cross-sectional }\end{array}$ & $\begin{array}{l}\text { Correlational, } \\
\text { cross- } \\
\text { sectional; } \\
\text { longitudinal }\end{array}$ \\
\hline
\end{tabular}


Table 2, part 4. Summary of the studies included in the review.

\begin{tabular}{|c|c|c|c|c|c|c|c|c|c|c|c|}
\hline Authors & $\begin{array}{l}\text { Lo-Fo-Wong } \\
\text { et al. }\end{array}$ & Lombart & Olchowska-Kotsala & Owens et al. & $\begin{array}{l}\text { Saher \& } \\
\text { Lindeman }\end{array}$ & Sirois. & Sirois \& Gick & Smith et al. & $\begin{array}{l}\text { Suarez \& } \\
\text { Reese }\end{array}$ & $\begin{array}{l}\text { Suarez \& } \\
\text { Reese }\end{array}$ & $\begin{array}{l}\text { Svedholm \& } \\
\text { Lindeman }\end{array}$ \\
\hline $\begin{array}{l}\text { Outcome } \\
\text { measure }\end{array}$ & $\begin{array}{l}\text { Provider - } \\
\text { directed } \\
\text { CAM use, } \\
\text { self-directed } \\
\text { CAM, self- } \\
\text { directed } \\
\text { CAM use } 6 \\
\text { moths follow- } \\
\text { up. }\end{array}$ & $\begin{array}{l}\text { Number of } \\
\text { UT tried. }\end{array}$ & $\begin{array}{l}\text { Willingness to use } \\
\text { CAM in } \\
\text { hypothetical } \\
\text { situations. }\end{array}$ & $\begin{array}{l}\text { Number of } \\
\text { therapies } \\
\text { used; } \\
\text { effectiveness } \\
\text { rating }\end{array}$ & $\begin{array}{l}\text { Self- } \\
\text { reported } \\
\text { belief in } \\
\text { efficacy of } \\
\text { CAM. }\end{array}$ & $\begin{array}{l}\text { Self-reported } \\
\text { CAM use. }\end{array}$ & $\begin{array}{l}\text { Self-reported CAM } \\
\text { use (Orthodox } \\
\text { medicine (non- } \\
\text { CAM), new or } \\
\text { infrequent CAM } \\
\text { use, established } \\
\text { CAM use). }\end{array}$ & $\begin{array}{l}\text { Willingness to use } \\
\text { CAM. }\end{array}$ & $\begin{array}{l}\text { Number of } \\
\text { CAM used }\end{array}$ & $\begin{array}{l}\text { Number of } \\
\text { CAM used }\end{array}$ & $\begin{array}{l}\text { Ratings of } \\
\text { CAM } \\
\text { effectiveness. }\end{array}$ \\
\hline $\begin{array}{l}\text { Outcome } \\
\text { measure tested } \\
\text { for reliability } \\
\text { and validity? }\end{array}$ & $\begin{array}{l}\text { Int. } \\
\text { consistency, } \\
\text { content } \\
\text { validity }\end{array}$ & Not tested & Internal consistency & Not tested & $\begin{array}{l}\text { Internal } \\
\text { consistency }\end{array}$ & Not tested. & Not tested. & $\begin{array}{l}\text { Content validity and } \\
\text { internal consistency. }\end{array}$ & $\begin{array}{l}\text { Internal } \\
\text { consistency }\end{array}$ & $\begin{array}{l}\text { Internal } \\
\text { consistency }\end{array}$ & $\begin{array}{l}\text { internal } \\
\text { consistency. }\end{array}$ \\
\hline Analysis & Regression & Regression & Regression & $\begin{array}{l}\text { Simple } \\
\text { correlations }\end{array}$ & Regression & Regression & Comparisons & Regression & Correlation & Regression & $\begin{array}{l}\text { simple } \\
\text { correlations }\end{array}$ \\
\hline $\begin{array}{l}\text { Cognitions/traits } \\
\text { related to CAM } \\
\text { use or belief }\end{array}$ & $\begin{array}{l}\text { OtE \& } \\
\text { provider } \\
\text { CAM, } \\
\text { (OR=1.14); } \\
\text { OtE \& self- } \\
\text { CAM 6 } \\
\text { months } \\
\text { (OR=1.11). }\end{array}$ & $\begin{array}{l}\text { OtE } \\
(\beta=.296) .\end{array}$ & $\begin{array}{l}\text { Emotionality } \\
(\beta=.48) ; \text { Rationality } \\
(\beta=.45) ; \\
\text { Neuroticism } \\
(\beta=.47) \text {; Extra'n } \\
(\beta=.46) ; \text { OtE }(\beta=- \\
.53) \text {. }\end{array}$ & $\begin{array}{l}\text { Number of } \\
\text { therapies \& } \\
\text { Absorpt.. } \\
(r=.49) ; \text { pos. } \\
\text { affect } \\
(r=.19) \text {; } \\
\text { Effectiveness } \\
\text { rating \& } \\
\text { Absorpt.. } \\
(r=.16) ; \text { pos. } \\
\text { affect }(r=.29)\end{array}$ & $\begin{array}{l}\text { Intuitive } \\
\text { thinking } \\
r=.33\end{array}$ & $\begin{array}{l}\text { Perceived } \\
\text { health control } \\
\text { (OR=1.47); } \\
\text { reward motiv. } \\
\text { (OR=1.56); } \\
\text { health due to } \\
\text { chance } \\
\text { (OR=0.81); } \\
\text { emotion } \\
\text { coping } \\
(\mathrm{OR}=0.65) \text {. }\end{array}$ & $\begin{array}{l}\text { OtE scores higher in } \\
\text { new \& infrequent } \\
\text { CAM users } \\
(\mathrm{M}=6.44, \mathrm{SD}=2.36) \\
\text { than non-CAM } \\
\text { users, }(\mathrm{M}=5.20 \text {, } \\
\mathrm{SD}=2.38)\end{array}$ & $\begin{array}{l}\text { OtE rel. CAM } \\
\text { ( } \beta=.225) \text {; Spirituality } \\
\text { rel. with CAM \& } \\
\text { spirituality- therapies } \\
(\beta=.274) ; \text { mood } \\
\text { attention ass with } \\
\text { CAM \& spirituality- } \\
\text { therapies ( } \beta=.182) \text {. }\end{array}$ & $\begin{array}{l}\text { Number of } \\
\text { CAM rel. PR } \\
\text { \& growth } \\
(r=.21) \text {; } \\
\text { active coping } \\
(r=.20) \text {; } \\
\text { planning } \\
(r=.29) \text {; } \\
\text { denial. }(r=- \\
.22) \text {; humour. } \\
(r=.26)\end{array}$ & $\begin{array}{l}\text { Number of } \\
\text { CAM rel. PR } \\
\text { \& growth } \\
(\beta=.29) ; \\
\text { active coping } \\
\text { ( } \beta=.24) ; \\
\text { planning } \\
\text { ( } \beta=.33) \text {; Soc. } \\
\text { sup. emot. } \\
(\beta=.26) ; \text { soc. } \\
\text { supp. instr. } \\
(\beta=.25) \text {; relig } \\
(\beta=.33)\end{array}$ & $\begin{array}{l}\text { Ontological } \\
\text { confusions } \\
(r=.22) ; \\
\text { Intuitive } \\
\text { thinking } \\
(r=.37) .\end{array}$ \\
\hline $\begin{array}{l}\text { Cognitions/traits } \\
\text { NOT related to } \\
\text { CAM use or } \\
\text { belief }\end{array}$ & $\begin{array}{l}\text { Perceived } \\
\text { control \& } \\
\text { self-CAM } 6 \\
\text { months } \\
(\mathrm{OR}=0.92) .\end{array}$ & $\begin{array}{l}\text { Neurot. ( } r=- \\
.08) \text {, } \\
\text { Compliance } \\
\text { (r=.03); } \\
\text { Humility } \\
(r=.03) ; \\
\text { Extra'n } \\
(r=.16) ; \text { Int. } \\
\text { LoC ( } r=.05) .\end{array}$ & $\begin{array}{l}\text { Intuition }(\beta=.04) ; \\
\text { Creativity }(\beta=-.05) \text {; } \\
\text { Conscientiousness } \\
(\beta=.12) ; \\
\text { Agreeableness } \\
(\beta=.30) \text {. }\end{array}$ & $\begin{array}{l}\text { Number of } \\
\text { therapies \& } \\
\text { neg. affect } \\
(r=-.06) \text {; } \\
\text { effectiveness } \\
\text { rating \& neg. } \\
\text { affect ( } r=- \\
.14)\end{array}$ & $\begin{array}{l}\text { Rational } \\
\text { thinking } \\
r=.00 .\end{array}$ & / & $\begin{array}{l}\text { Group comparisons } \\
\text { not significant on } \\
\text { neuro'm., extra'n, } \\
\text { agreeableness and } \\
\text { conscientiousness, } \\
\text { int. LoC and ext. } \\
\text { LoC. }\end{array}$ & $\begin{array}{l}\text { Neurot’m, Extra., } \\
\text { Agreeableness, } \\
\text { Conscientiousness, } \\
\text { Mood Clarity, Mood } \\
\text { Repair, optimism, } \\
\text { religiousness. }\end{array}$ & $\begin{array}{l}\text { Accept.; } \\
\text { behav. disen.; } \\
\text { Soc. sup. } \\
\text { emot.; soc. } \\
\text { supp. instr.; } \\
\text { suppr. comp. } \\
\text { act.; relig.; } \\
\text { mental } \\
\text { diseng; } \\
\text { venting; rest.; } \\
\text { Alcohol. }\end{array}$ & $\begin{array}{l}\text { Accept., } \\
\text { behav. disen., } \\
\text { denial, } \\
\text { humour, } \\
\text { suppressing } \\
\text { competing } \\
\text { activities }\end{array}$ & $\begin{array}{l}\text { Need for } \\
\text { cognition } \\
(r=.12) ; \\
\text { Actively } \\
\text { open-minded } \\
\text { thinking ( } r=- \\
.19) \text {. }\end{array}$ \\
\hline
\end{tabular}


Table 2, part 5. Summary of the studies included in the review.

\begin{tabular}{|c|c|c|c|c|}
\hline Authors & Takeda et al. & Tarhan et al. & Wheeler \& Hyland & Won \\
\hline Year & 2012 & 2011 & 2008 & 2014 \\
\hline Country & Japan & Turkey & UK & USA \\
\hline Setting & Secondary care, cancer & Secondary care, cancer & University & Gen. public, online \\
\hline Population & $\begin{array}{l}\text { Gynecologic cancer } \\
\text { patients in Japan }\end{array}$ & $\begin{array}{l}\text { Oncology patients in } \\
\text { Turkey }\end{array}$ & Students & Gen. public \\
\hline Sample size & 420 & 220 & 131 & 100 \\
\hline Study aims & $\begin{array}{l}\text { Characteristics, } \\
\text { perceptions and } \\
\text { attitudes of cancer } \\
\text { patients to Kampo } \\
\text { medicines }\end{array}$ & $\begin{array}{l}\text { Whether disease state, } \\
\text { sociodemographics } \\
\text { psychological } \\
\text { conditions and QoL } \\
\text { predict CAM use }\end{array}$ & $\begin{array}{l}\text { Whether thinking style } \\
\text { and absorption predict } \\
\text { use of CAM }\end{array}$ & $\begin{array}{l}\text { Traits, thinking style, } \\
\text { rel. with CAM } \\
\text { use/belief }\end{array}$ \\
\hline Design & $\begin{array}{l}\text { Quasi experimental } \\
\text { comparison, cross- } \\
\text { sectional }\end{array}$ & $\begin{array}{l}\text { Quasi-experimental, } \\
\text { cross-sectional }\end{array}$ & $\begin{array}{l}\text { Correlational, cross- } \\
\text { sectional }\end{array}$ & $\begin{array}{l}\text { Correlational, cross- } \\
\text { sectional }\end{array}$ \\
\hline
\end{tabular}


Table 2, part 6. Summary of the studies included in the review.

\begin{tabular}{|c|c|c|c|c|}
\hline Authors & Takeda et al. & Tarhan et al. & Wheeler \& Hyland & Won \\
\hline $\begin{array}{l}\text { Outcome } \\
\text { measure }\end{array}$ & $\begin{array}{l}\text { Whether users, or non- } \\
\text { users of Kampo/ dietary } \\
\text { supplements }\end{array}$ & Self-reported CAM use. & $\begin{array}{l}\text { Self-reported CAM } \\
\text { use, practitioner and } \\
\text { self. }\end{array}$ & $\begin{array}{l}\text { Self-reported CAM use/ attitude to } \\
\text { CAM. }\end{array}$ \\
\hline $\begin{array}{l}\text { Outcome } \\
\text { measure tested } \\
\text { for reliability } \\
\text { and validity? }\end{array}$ & Not tested & Not tested. & Not tested & Internal reliability, test-retest. \\
\hline Analysis & Multivariate risk ratio & $\begin{array}{l}\text { Simple group } \\
\text { comparisons. }\end{array}$ & Simple correlations & \\
\hline $\begin{array}{l}\text { Cognitions/traits } \\
\text { related to CAM } \\
\text { use or belief }\end{array}$ & $\begin{array}{l}\text { Trait anxiety (risk ratio, } \\
\text { 1.46) }\end{array}$ & l & $\begin{array}{l}\text { Practitioner. CAM } \\
\text { use rel. rational } \\
\text { thinking }\left(r_{p b}=-.29\right) \text {, } \\
\text { absorpt. }\left(r_{p b}=.22\right) \text {; } \\
\text { self CAM use rel. } \\
\text { rational thinking } \\
\left(r_{p b}=-.25\right), \text { intuitive } \\
\text { thinking }\left(r_{p b}=.27\right) \text {, } \\
\text { absorpt. }\left(r_{p b}=.41\right)\end{array}$ & $\begin{array}{l}\text { Rel. to CAM use: OtE }(B=.23) \text {; } \\
\text { Emot. intell. }(B=-.27 ; .20) \text {; Intuitive } \\
\text { thinking }(B=.22) \text {; } \\
\text { Rel. to CAM attitude: Sex }(B=.29)\end{array}$ \\
\hline $\begin{array}{l}\text { Cognitions/traits } \\
\text { NOT related to } \\
\text { CAM use or } \\
\text { belief }\end{array}$ & & $\begin{array}{l}\text { State/trait anxiety (STAI), } \\
\text { CAM users } \mathrm{M}=43.7 \\
(\mathrm{SD}=8.0) \text {, non-CAM users } \\
\mathrm{M}=44.3(\mathrm{SD}=8.2) \text {. }\end{array}$ & $\begin{array}{l}\text { Practitioner CAM } \\
\text { use not rel. intuitive } \\
\text { thinking }\end{array}$ & $\begin{array}{l}\text { Not rel. to CAM attitude: OtE } \\
(B=.08) \text {; Intuitive thinking }(B=.16) \text {. }\end{array}$ \\
\hline
\end{tabular}


Figure 1. PRISMA flow diagram of search process.
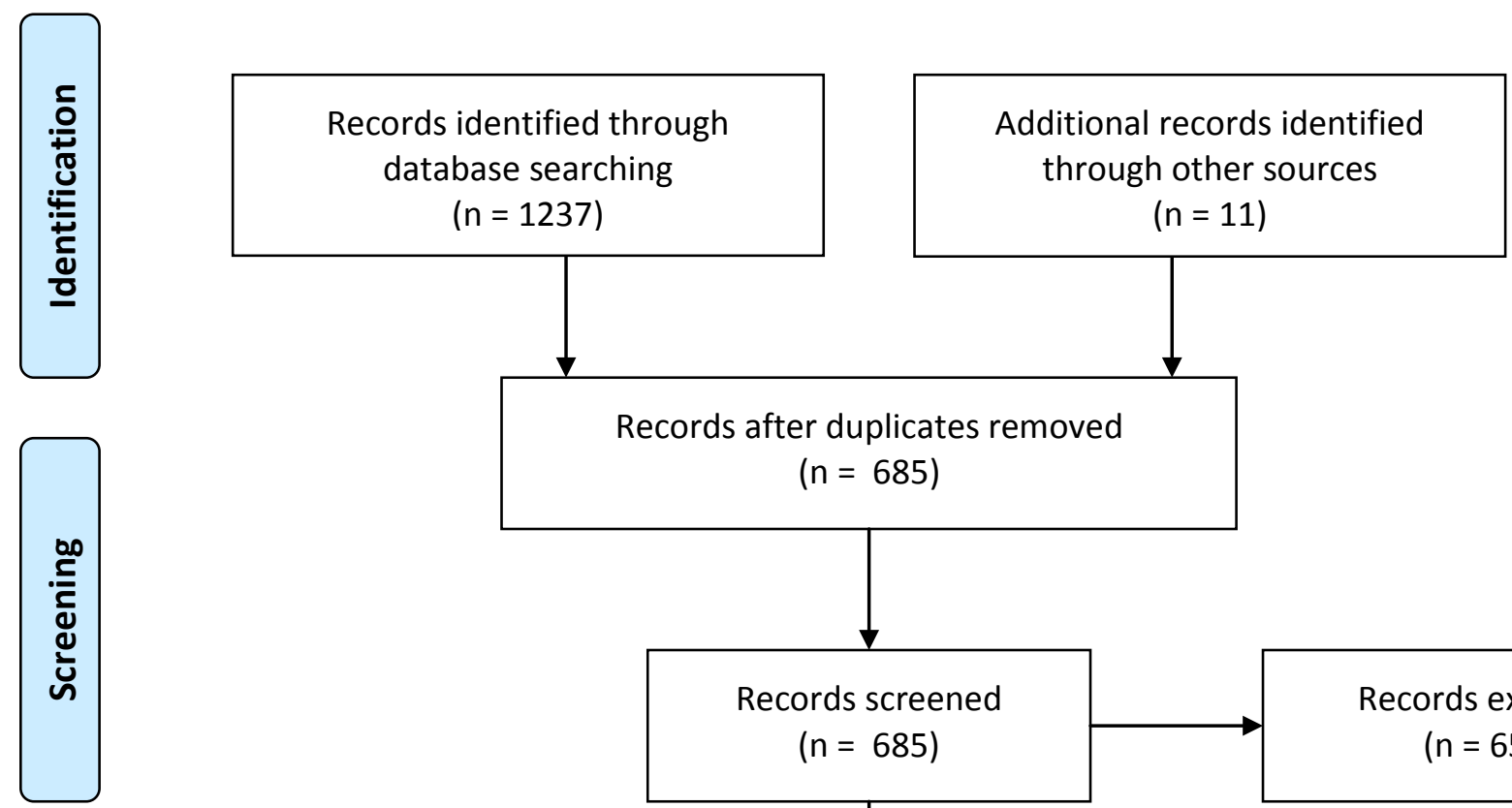

Records after duplicates removed

$$
(n=685)
$$

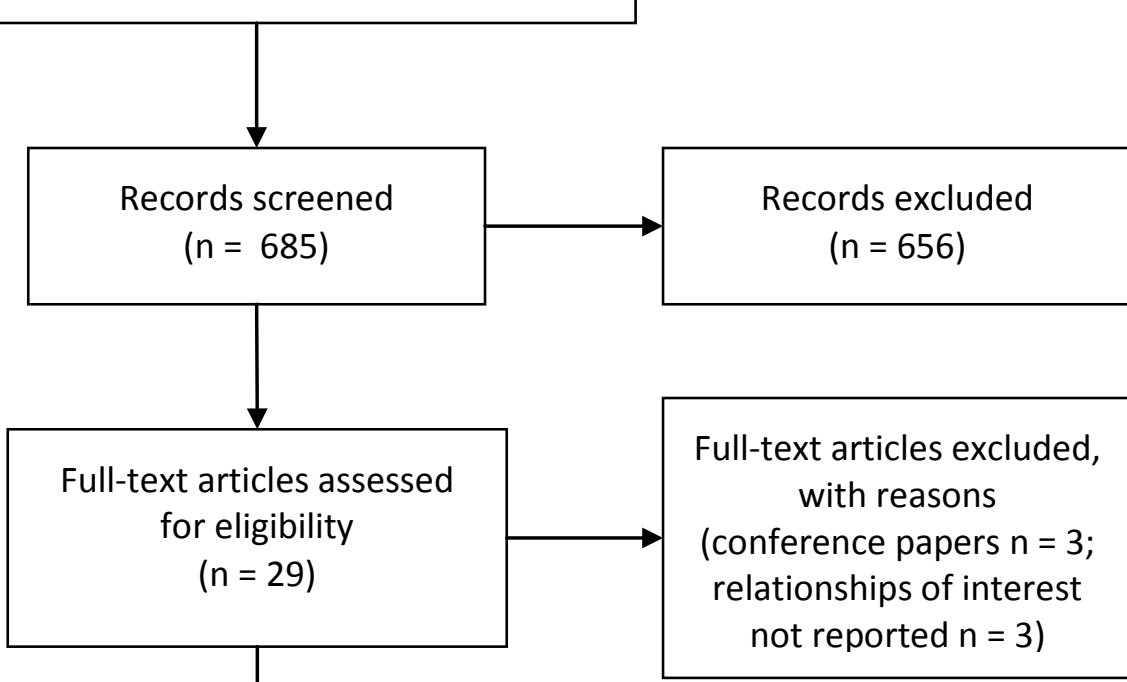

Studies included in qualitative synthesis $(n=23)$ 